\title{
1 Guidelines on red cell transfusion in sickle cell 2 disease Part II: indications for transfusion
}

BRITISH COMMITTEE FOR StANDARdS IN HAEMATOLOGY

6

7

8 ADDRESS FOR CORRESPONDENCE:

9 BCSH SECRETARY

10 BRITISH SOCIETY OF HAEMATOLOGY

11100 WHITE LION STREET

12 LONDON N1 9PF

13 e-mail: bcsh@b-s-h.org.uk

\section{Writing group:}

B.A. Davis ${ }^{1}$, S. Allard², A. Qureshi ${ }^{3}$, J.B. Porter ${ }^{4}$, S. Pancham ${ }^{5}$, N. Win' ${ }^{6}$, G. Cho ${ }^{7}$, K. Ryan $^{8}$

\section{Disclaimer:}

While the advice and information in these guidelines is believed to be true and accurate at the time of going to press, neither the authors, the British Society for Haematology nor the publishers accept any legal responsibility for the content of these guidelines.

\footnotetext{
${ }^{1}$ Whittington Hospital, London

${ }^{2}$ Barts and The London NHS Trust \& NHS Blood and Transplant

3John Radcliffe Hospital, Oxford

${ }^{4}$ University College London Hospitals NHS Foundation Trust

${ }^{5}$ City Hospital, Birmingham

${ }^{6}$ NHS Blood and Transplant

7 London North West Healthcare NHS Trust

8 Central Manchester University Hospitals NHS Foundation Trust
} 


\section{INTRODUCTION}

2 Red cell transfusion has an important role in the management of sickle cell disease

3 (SCD) in both emergency and elective settings. However, because of insufficient

4 randomised data, it is not always clear when or how to use red cell transfusion. A

5 companion BCSH guideline addressed general principles of transfusion practice in

6 SCD (Davis et al.....). The present guideline examines current available evidence on

7 indications for transfusion in SCD. This may not be appropriate for all clinical

8 scenarios and clinical decisions must be based on individual patient considerations.

9 In both guidelines, the term sickle cell disease refers to all genotypes of the disease,

10 and sickle cell anaemia to the homozygous state (SS).

11

\section{METHODS}

13 The writing group was selected by the BCSH General Haematology and Transfusion

14 Task Forces with input from other experts in Haemoglobinopathy. MEDLINE and

15 EMBASE were searched systematically for publications from 1960 to 2015 using a

16 variety of key words. Opinions were also sought from experienced haematologists

17 with a special interest in the care of SCD patients. The guideline was reviewed by the members of the General Haematology Task Force of the BCSH prior to being sent to a sounding board of approximately $50 \mathrm{UK}$ haematologists, the $\mathrm{BCSH}$ and the BSH Committee. Comments were incorporated where appropriate. The Grading of

21 Recommendations Assessment, Development and Evaluation (GRADE) nomenclature was used to evaluate levels of evidence and to assess the strength of recommendations. The GRADE criteria are specified in the BCSH guidance pack http://www.bcshquidelines.com/BCSH PROCESS/EVIDENCE LEVELS AND GRA DES OF RECOMMENDATION/43 GRADE.html and the GRADE working group website http://www.gradeworkinggroup.org. 
1 Key recommendations

2 Consideration of sickle cell patients for transfusion, particularly long-term

3 regimens, should weigh up the potential benefits against potential risks (Grade

4 1C).

6 Cerebrovascular disease:

7 Regular transfusion to maintain $\mathrm{HbS}<\mathbf{3 0 \%}$ should be offered as initial

8 treatment to children with $\mathbf{S S}$ or $\mathbf{S} / \boldsymbol{\beta}^{\circ}$ thalassaemia aged 2-16 years judged to

9 be at high risk for a first stroke on the basis of Transcranial Doppler

10 ultrasonography (TCD) (Grade 1A).

11

12 Hydroxycarbamide treatment should be considered for the primary prevention

13 of stroke in children with sickle cell anaemia and high TCD velocities but not

14 severe Magnetic Resonance Angiography (MRA)-defined cerebral

15 vasculopathy after an initial period of transfusions (Grade 1A). The duration of

16 the initial period of transfusion should be tailored to the individual patient but

17 should be for a minimum of 1 year; the transition to hydroxycarbamide should

18 be done gradually and transfusion should be withdrawn after the

19 hydroxycarbamide has been escalated to the maximum tolerated dose.

21 Regular transfusion to maintain $\mathrm{HbS}<\mathbf{3 0} \%$ effectively reduces the incidence of recurrence of cerebral infarction (defined as a stroke or a new or enlarged silent cerebral infarct) in children with sickle cell anaemia and_S $S \beta^{\circ}$ thalassaemia aged 5-15 years. Treatment options including transfusion should be discussed with families of children who are found to have silent cerebral infarcts. Transfusion should be offered to children who are identified to be at greatest risk for recurrence of infarction after discussion of its benefits and risks (Grade 1A)

30 Long-term transfusion to maintain $\mathrm{HbS}<\mathbf{3 0} \%$ is recommended for the

31 prevention of recurrent ischaemic stroke due to sickle cell disease in both 
1 children and adults (Grade 1B)

2

3 Adults or children who present with signs or symptoms suggestive of acute

4 ischaemic stroke should be transfused without any delay to maintain $\mathrm{HbS}$

$5<30 \%$ pending further investigation. Those with confirmed stroke due to sickle

8 Surgery

9 Preoperative transfusion is recommended for SS patients undergoing medium-

10 risk surgery (e.g. abdominal, tonsillectomy, orthopaedic) (Grade 1A). cell disease should continue regular transfusions long-term (Grade 1B).

\section{Preoperative transfusion is recommended for SC patients undergoing} medium-risk surgery (e.g. abdominal, tonsillectomy, orthopaedic) (Grade 1C).

Transfusion is recommended for sickle cell patients of all genotypes requiring high-risk surgery (e.g. cardiovascular, brain) (Grade 1C).

All sickle cell patients with other genotypes undergoing surgery should be individually assessed taking into account previous history and complexity of surgery, and a management plan should be formulated to include the need for transfusion (Grade 1C)

Particular care should be taken to ensure that all aspects of perioperative care including oxygenation, hydration, warmth and anaesthetic and surgical technique are optimised in all sickle cell patients undergoing surgery (Grade 1C).

For patients requiring emergency surgery, the urgency and complexity of the procedure should be taken into account in the timing of perioperative transfusion. Simple transfusion should be given preoperatively if $\mathrm{Hb}<90 \mathrm{~g} / \mathrm{l}$ provided this will not result in undue delay to surgery. If transfusion is likely to cause an unacceptable delay to surgery, it is reasonable to proceed to surgery 
1 while arranging to transfuse the patient intra- or post-operatively if necessary

2 (Grade 1D).

3

4 Acutely ill patients

5 Transfusion (excahnge or top up?) is recommended and may be life-saving in

6 acute sickle complications such as splenic sequestration, hepatic sequestration, aplastic crisis and severe acute chest syndrome (Grade 1B).

Transfusion should be considered in the unwell patient with acute multi-organ failure, mesenteric syndrome (Grade $1 \mathrm{C}$ ) and patients with severe sepsis (Grade $2 \mathrm{C}$ ). Such cases should be discussed with the specialist haemoglobinopathy team (SHT).

Transfusion for other causes of acute anaemia requires individual assessment and should be discussed with the SHT. Transfusion may be given by simple transfusion (top up) or exchange depending on clinical severity under the guidance of the SHT (Grade 2C).

\section{Pregnancy}

Transfusion is not routinely required for uncomplicated singleton pregnancies.

\section{(Grade 1B).}

Transfusion should be considered in women with previous or current serious medical, obstetric or fetal problems, women with worsening anaemia, those on long-term transfusions for stroke prevention or for amelioration of severe sickle complications, women on hydroxycarbamide because of severe disease and those with multiple pregnancy (Grade 1C).

\section{Amelioration of severe disease}

In selected patients with severe disease, blood transfusion can be effective in ameliorating disease, resulting in reduction in hospital bed days. 
1 Hydroxycarbamide is recommended as first line treatment for prevention of

2 recurrent acute chest syndrome or repeated painful episodes associated with

3 chest syndrome (Grade 1A). Regular transfusion should be considered for

4 patients failing this treatment or for whom hydroxycarbamide is

5 contraindicated or not acceptable (Grade 1B).

6

7 Other indications

8 Transfusion is not recommended to treat steady state anaemia provided that

$9 \quad \mathrm{Hb}$ has not fallen over a period of time to symptomatic levels (e.g. with

10 developing chronic kidney disease) (Grade 1C).

There is no evidence that transfusion shortens the duration of a painful crisis. Transfusion is not recommended in uncomplicated painful crises but should be considered if there is a substantial drop in $\mathrm{Hb}$ from baseline (e.g. $>20 \mathrm{~g} / \mathrm{l}$ or to $\mathrm{Hb}<50 \mathrm{~g} / \mathrm{l}$ ), haemodynamic compromise or concern about impending critical organ complications (Grade 1C).

The benefit of transfusion to relieve established acute priapism has not been shown in randomised controlled trials. Many patients require a shunt or drainage procedure under general anaesthesia which may require a transfusion. Such cases should be discussed with the SHT (Grade 2C).

Transfusion has been shown to reduce the incidence of symptomatic avascular necrosis in children receiving regular transfusions to maintain $\mathrm{HbS}$ $<30 \%$ for prevention of recurrence of cerebral infarction (Grade 1A). However, there is no consensus on the use of transfusion for the sole purpose of preventing this complication in routine practice.

Where transfusion is considered for indications where there is insufficient evidence for its benefit (e.g. leg ulcers, pulmonary hypertension, end stage renal or liver disease, progressive sickle cell retinopathy), a full risk-benefit assessment should be carried out in liaison with the SHT and each case 
1 should be considered on its own merits (Grade 2C).

\section{INDICATIONS FOR TRANSFUSION IN SICKLE CELL DISEASE}

The indications for red cell transfusion in SCD range from those in which transfusion can be strongly recommended to those where its use is unproven or controversial. A case-by-case detailed analysis of risk and benefit of red cell transfusion should be undertaken for unproven or controversial indications. (1)

The indications can be broadly categorised into conditions in which correction of anaemia is the main goal and those where reduction of sickle haemoglobin $(\mathrm{HbS})$ may be more appropriate (see Table 1). In both categories, transfusion is either performed acutely, as part of the management of an acute complication of SCD, or electively for the prevention or management of disease complications. Elective transfusions may be one-off (e.g. preoperative) or be part of a long-term transfusion programme.

The decision to transfuse any patient with SCD should be taken by senior medical staff, ideally at consultant level with the appropriate experience. Long-term elective transfusions should usually be initiated by or in consultation with a specialist haemoglobinopathy team (SHT).

It should be recognised that the low steady state $\mathrm{Hb}$ in SCD is the result of the low oxygen affinity of haemoglobin $S$ and is therefore not in itself an indication or transfusion.

\section{INDICATIONS FOR EMERGENCY TRANSFUSION}

4.1. Emergency transfusion with the primary aim of correcting acute anaemia

\subsubsection{Ascertaining the cause of anaemia}


1 Acute anaemia in SCD has been defined as a fall in haemoglobin $\geq 20 \mathrm{~g} / \mathrm{l}$ below the

2 steady state value (Emond, et al 1985, NHLBI 2014). Understanding the cause of the

3 anaemia is essential for appropriate management. Causes broadly include:

4 decreased production, sequestration and increased haemolysis. Initial assessment

5 should include: history of recent transfusion, haemodynamic status, spleen and liver

6 size, full blood count and reticulocyte count. Any decision to transfuse should take

7 into consideration the likely cause, haemodynamic status and degree of anaemia

8 relative to baseline.

$10 \quad$ 4.1.2 Aplastic crisis

11 Aplastic crisis should be suspected in patients with acute exacerbation of steady

12 state anaemia with reticulocytopenia and is usually due to infection with human

13 erythrovirus (formerly parvovirus) B19 (Goldstein, et al 1987, Pattison, et al 1981,

14 Serjeant, et al 1993, Serjeant, et al 1981). Anaemia is usually severe with a mean

15 fall of approximately $40 \mathrm{~g} / \mathrm{l}$ below steady state values (Goldstein, et al 1987,

16 Serjeant, et al 2001).

18 Simple transfusion to steady state level is usually all that is required to maintain the oxygen carrying capacity of blood (Goldstein, et al 1987, Serjeant, et al 1993, SmithWhitley, et al 2004). Spontaneous resumption of erythropoiesis tends to occur within 7-10 days of aplasia (Anderson, et al 1985), restoring the $\mathrm{Hb}$ to the steady state value. Most patients will be close to spontaneous marrow recovery at the time of clinical presentation with development of reticulocytosis and recovery of $\mathrm{Hb}$ occurring $<7$ days from presentation (Serjeant, et al 1993).

Erythrovirus B19 may occasionally present with serious and potentially lifethreatening complications including acute splenic sequestration, acute chest syndrome (ACS) (Lowenthal, et al 1996, Smith-Whitley, et al 2004) or acute neurological syndromes including stroke (Balkaran, et al 1992, Wierenga, et al 2001). In such cases, exchange transfusion may be more appropriate.

\subsubsection{Acute splenic sequestration}


1 Acute splenic sequestration is characterised by an acute fall in $\mathrm{Hb} \geq 20 \mathrm{~g} / \mathrm{l}$,

2 reticulocytosis and sudden splenic enlargement (Emond, et al 1985), and in severe

3 cases may result in circulatory failure and even death (Emond, et al 1985, Rogers, et

4 al 1978). Although splenic sequestration typically occurs in the first 5 years of life

5 (Topley, et al 1981) before the spleen has spontaneously infarcted, it may

6 occasionally occur later particularly in those with milder disease such as SC disease

7 in whom splenic infarction may not occur until later in life (Aslam, et al 2005,

8 Roshkow and Sanders 1990). Immediate management consists of simple

9 transfusion to raise the $\mathrm{Hb}$ to steady state level (Emond, et al 1985). Transfusion

10 with emergency (O Rh (D) negative) or ABO- and Rh (D)-specific uncrossmatched

11 blood may occasionally be necessary to treat shock and anaemia in extremis. In

12 many cases, however, cautious transfusion of small red cell volumes to raise the

13 haemoglobin to the steady state level is sufficient to reverse the process and correct

14 hypovolaemia and anaemia. Transfusion of large volumes of red cells should be

15 avoided due to the risk of hyperviscosity when sequestered red cells return to the

16 circulation (Josephson, et al 2007, Kinney, et al 1990, Quirolo 2010, Wanko and

17 Telen 2005)

All patients with previous splenic sequestration should be discussed with the SHT.

There is a high recurrence rate (Brousse, et al 2012, Emond, et al 1985) and splenectomy is advised in patients who have recurrent episodes (two or more).

Splenectomy is not associated with an increased long-term risk of bacteraemic episodes or death (Wright, et al 1999). Regular transfusion to maintain $\mathrm{HbS}<30 \%$ did not reduce the risk of recurrence or need for splenectomy after splenic sequestration compared to clinical observation in a retrospective observational study 26 (Kinney, et al 1990).

\subsubsection{Acute hepatic sequestration}

29 Acute hepatic sequestration presents with acute hepatic enlargement associated with a fall in $\mathrm{Hb} \geq 20 \mathrm{~g} / \mathrm{l}$ and rise in the reticulocyte count. It usually responds to simple transfusion or exchange transfusion (Gutteridge, et al 1985, Hatton, et al 
1 splenic sequestration, the return of sequestered red cells into the circulation may

2 cause acute hyperviscosity (Lee and Chu 1996) and cautious transfusion of small

3 volumes of red cells is recommended.

4

4.1.5 Delayed haemolytic transfusion reaction (classical and hyperhaemolysis syndrome)

7 A delayed haemolytic transfusion reaction (DHTR) (classical or hyperhaemolysis)

8 must be strongly suspected in patients presenting with acute anaemia with/without

9 pain typical of vaso-occlusive crisis following a recent transfusion (King, et al 1997,

10 Milner, et al 1985, Petz, et al 1997). Hyperhaemolysis may be missed because it is

11 assumed that the patient's symptoms are due entirely to a painful crisis. The investigation and management of these two syndromes have been described in the companion guideline (Davis et al, ........)

All cases of DHTR and hyperhaemolysis should be discussed with the SHT both for advice on management and because of the long-term implications of alloimmunisation and risk of hyperhaemolysis recurrence.

\subsubsection{Increased haemolysis during painful crises}

Transfusion is not recommended in uncomplicated painful crises. Although $\mathrm{Hb}$ often drops to slightly below steady state levels, transfusion is typically not required and $\mathrm{Hb}$ will return to baseline as the crisis abates. Transfusion may be indicated if there is a substantial drop in $\mathrm{Hb}$ from baseline (e.g. $>20 \mathrm{~g} / \mathrm{l}$ or $\mathrm{Hb}<50 \mathrm{~g} / \mathrm{l}$ ), haemodynamic compromise or concern about impending critical organ complications (see below).

\subsubsection{Other causes of exacerbation of anaemia}

An acute decline in $\mathrm{Hb}$ due to haemolysis is common in acute sickle complications such as acute chest syndrome (ACS) (Howard, et al 2015) and acute multi-organ failure syndrome (Hassell, et al 1994). The role of transfusion in these two syndromes is described in sections 4.2.1 and 4.2.3. Urgent transfusion is indicated for acute blood loss. 
1 Severe anaemia during hydroxycarbamide therapy requiring transfusion is usually

2 due to an acute intercurrent illness such as acute splenic sequestration, aplastic

3 crisis or ACS rather than the myelosuppressive effects of the drug (Gulbis, et al

4 2005, Hankins, et al 2005b, Kinney, et al 1999, Scott, et al 1996, Wang, et al 2001).

5 The effects of myelosuppression are usually reversible rapidly upon reduction of the

6 dose or temporary cessation of hydroxycarbamide but full recovery may not occur for

7 several weeks (Hankins, et al 2005b, Wang, et al 2001).

9 In patients with sickle cell nephropathy, a slow decline of haemoglobin concentration

10 occurs as the renal disease progresses and the anaemia may be severe enough to

11 compromise cardiovascular function (Serjeant 2001).

Recommendations

14 Simple transfusion to steady state haemoglobin concentration is indicated for patients with acute exacerbation of anaemia as a result of aplastic crisis or sequestration crisis (Grade 1B).

Transfusion is not recommended in uncomplicated vaso-occlusive crisis but should be considered if there is worsening anaemia, haemodynamic compromise or concern about impending critical organ complications (Grade 1C).

Transfusion for other causes of acute anaemia requires individual assessment and should be discussed with the specialist haemoglobinopathy team (SHT) (Grade 1C).

4.2 Emergency transfusion with the primary aim of reducing $\mathrm{HbS}$ in relation to $\mathrm{HbA}$

30 Transfusion to reduce the $\% \mathrm{HbS}$ is indicated where there is evidence of acute critical organ complications, especially acute chest syndrome (ACS) and ischaemic stroke. 


\section{$1 \quad$ 4.2.1 Acute chest syndrome (ACS)}

2 ACS usually develops during a painful crisis and should be suspected in patients

3 presenting with fever and/or respiratory symptoms, together with clinical signs of 4 lung consolidation (Howard, et al 2015). Early recognition of ACS and intervention

5 with blood transfusion can be life-saving.

6

ACS can develop rapidly and progress to acute respiratory failure within a few hours. It is advisable to plan to have blood available if early signs of ACS occur, even if other measures subsequently render transfusion unnecessary. Both simple and exchange transfusion rapidly improved oxygenation with similar efficacy in nonrandomised studies (Turner, et al2009, Vichinsky, et al 2000). A simple transfusion aiming for a target $\mathrm{Hb} 100-110 \mathrm{~g} / \mathrm{l}$ is effective in preventing progression to acute respiratory failure in patients with mild ACS if it is given early in the illness (Emre, et al 1995) and should be considered in patients with a $\mathrm{PaO} 2<9.0 \mathrm{kPa}$ on room air, but may also be needed at less severe degrees of hypoxaemia, depending on the individual patient's history and clinical features, or if the patient's oxygen requirements are increasing (Howard, et al 2015). Exchange transfusion is recommended in patients with features of severe ACS, those who fail to respond to initial simple transfusion, or patients with a higher $\mathrm{Hb}(>90 \mathrm{~g} / \mathrm{l})$ where there is little leeway for simple transfusion (Emre, et al 1995, Howard, et al 2015, NHLBI 2014, Vichinsky, et al 1997).

There is no evidence as to the optimal \% $\mathrm{HbS}$ target post-exchange transfusion. In practice a target of $<30-40 \%$ is often used, but clinicians should be guided by the clinical response (Howard, et al 2015).

Guidelines for the diagnosis and management of ACS are available from the BCSH (Howard, et al 2015).

\subsubsection{Acute ischaemic stroke}

The value of transfusion and the comparative effects of exchange versus simple transfusion in acute ischaemic stroke have not been evaluated in randomised trials. 
1 Emergency exchange transfusion to reduce $\mathrm{HbS}$ to $<30 \%$ is recommended for acute

2 ischaemic stroke (NHLBI 2014, RCP 2004, Sickle Cell Society 2008). Initial simple

3 transfusion should be given if the stroke has occurred in the context of severe acute anaemia (e.g. in aplastic crisis) (RCP 2004). Although there are no controlled trials on the effect of transfusion on the stroke itself, red cell transfusion may potentially minimise morbidity and mortality by improving perfusion and oxygenation to the brain, thereby preventing extension of an infarct. There is evidence from a retrospective cohort study that exchange transfusion for a first overt stroke at the time of stroke presentation is associated with a lower risk of a subsequent stroke compared to simple transfusion (Hulbert, et al 2006). It is important to avoid hypovolaemia during the procedure and to keep the post-transfusion $\mathrm{Hb}$ at a target of $100 \mathrm{~g} / \mathrm{l}$, as a high haematocrit associated with hyperviscosity may worsen the neurological insult.

Current pathways for acute stroke care in the UK require adult patients with suspected stroke to be admitted directly to specialist stroke units (hyperacute stroke units) (NICE 2008). NHS Trusts must ensure that governance arrangements are in place to provide specialist haemoglobinopathy care for SCD patients with suspected stroke who are admitted to hyperacute stroke units so that emergency exchange transfusion can be provided in a timely manner. Although this model of care has not been developed for paediatrics, NHS Trusts must develop local protocols with the collaboration of their SHT so that SCD children with acute stroke can receive appropriate care, including timely exchange transfusion and specialist neurology advice (Dick 2010, RCP 2004).

There are currently no data to support the use of red cell transfusion either in the acute management of haemorrhagic stroke or to prevent its recurrence and it is recommended that specialist advice is sought for individual cases.

\subsubsection{Acute multi-organ failure syndrome}

31 This is a severe life-threatening syndrome that may complicate a severe painful crisis. It is particularly likely to occur in patients with otherwise mild sickle cell 
1 disease and a relatively high haemoglobin concentration. The patient presents with

2 multi-organ failure with associated fever, rapid decrements in $\mathrm{Hb}$ and platelet count,

3 non-focal encephalopathy and rhabdomyolysis. The syndrome usually responds to

4 aggressive exchange transfusion (Hassell, et al 1994)

\subsubsection{Mesenteric ("girdle") syndrome}

8 This is a rare severe sequestration syndrome characterised by simultaneous or

9 consecutive sickling and sequestration in the mesenteric vascular bed, liver and

10 lungs (Brozovic, et al 1987). Preceding pain in the abdomen, lumbar spine and limbs

11 is common. Sickling in the abdomen can present with tenderness and rigidity,

12 mimicking peritonitis and progressing to ileus, with a silent distended abdomen and

13 dilated loops of bowel on X-ray. Acute chest syndrome frequently develops due to

14 splinting of the chest wall. Acute exchange blood transfusion is indicated.

\subsubsection{Severe sepsis}

17 Severe sepsis often engenders a vicious circle of tissue hypoxia, acidosis and sickling. An exchange transfusion or simple transfusion may be useful in correcting anaemia, improving microvascular blood flow, improving tissue oxygenation and the patient's overall clinical condition (Ohene-Frempong 2001)

\subsubsection{Acute intrahepatic cholestasis}

23 This is a rare and little understood complication that presents with extreme

24 conjugated and unconjugated hyperbilirubinaemia (relative to the steady state bilirubin), marked elevation of the alkaline phosphatase and variable rises in transaminase levels. There is a high mortality from liver failure or bleeding. There is no established treatment but exchange transfusion appears to be beneficial (Shao and Orringer 1995).

\subsubsection{Acute priapism}

31 The treatment of priority in acute fulminant priapism is penile aspiration/irrigation followed by the intracavernosal injection of sympathomimetic drugs if aspiration fails 
1 to resolve the problem (Montague, et al 2003). This initial urological intervention

2 should not be delayed while a transfusion is arranged.

3

Neither simple nor exchange transfusion have been evaluated for acute management of priapism in randomised controlled trials. Small case series and literature reviews provide no evidence of amelioration of pain or duration of priapism once this has been established. (McCarthy, et al2000, Merritt, et al 2006). Surgical management is indicated if initial urological measures are not effective (Montague, et al 2003). Shunt procedures for the relief of acute priapism require a general anaesthetic so that the patient may benefit from transfusion, as with other surgical procedures (Howard, et al 2013). If patients do not respond to initial shunt procedures there may be benefit from exchange transfusion to decrease $\% \mathrm{HbS}$. Local hospitals should develop referral pathways so that patients requiring specialist surgery are transferred promptly to tertiary centres. Such patients must be discussed with the SHT with regards to possible transfusion pre-operatively.

\section{Recommendations}

Transfusion is recommended in cases of acute chest syndrome (ACS) with hypoxia. Transfusion may be given by simple or exchange transfusion depending on clinical severity under the guidance of the SHT (Grade 1B).

Adults or children with signs or symptoms suggestive of acute ischaemic stroke should be transfused to sickle haemoglobin $(\mathrm{HbS})<30 \%$ pending further investigation. Those with confirmed stroke due to sickle cell disease should continue regular transfusions indefinitely (Grade 1B).

Transfusion should be considered in the unwell patient with acute multi-organ failure, mesenteric syndrome (Grade 1C) and patients with severe sepsis (Grade 2C). Such cases should be discussed with the SHT.

The benefit of transfusion to relieve established acute priapism has not been shown in randomised controlled trials. Many patients require a shunt or 
1 drainage procedure under general anaesthesia, which may require a

2 transfusion. Such cases should be discussed with the SHT (Grade 2C).

3

4

5

6

\section{INDICATIONS FOR CHRONIC TRANSFUSION}

The best data to support chronic transfusion programmes are for the primary prevention of stroke (Adams and Brambilla 2005, Adams, et al 1998) and secondary prevention of silent cerebral infarcts in paediatric populations (DeBaun, et al 2014).

There is also good evidence for the effectiveness of transfusions in preventing recurrent stroke in children (Pegelow, et al 1995, Scothorn, et al 2002).

Chronic exchange transfusion has been utilised for a wide variety of indications including prevention of recurrent vaso-occlusive crises and recurrent chest syndrome. In many of these circumstances there is also evidence of benefit of hydroxycarbamide therapy (Charache, et al 1995, Thornburg, et al 2012) and chronic transfusion should only be contemplated where hydroxycarbamide is ineffective or contra-indicated.

Where chronic transfusion is initiated outside the context of paediatric stroke, the parameters to assess efficacy should be clearly documented and the risks and benefits for the patient regularly reviewed. Outcomes of chronic transfusion programmes should be regularly audited across centres. Decisions to initiate chronic transfusion should be made by the SHT.

\subsection{Primary and secondary stroke prevention}

Long-term red cell transfusion is the mainstay of treatment for the primary and secondary prevention of stroke due to SCD. Evidence for the efficacy of transfusion for primary stroke prevention is available only for children but the principles may be relevant for adult patients (over 16 years).

\subsubsection{Primary stroke prevention in children with SCD}

Regular red cell transfusion to maintain $\mathrm{HbS}$ level $<30 \%$ is indicated for the primary 
1 prevention of stroke in children (2-16 years) with $S S$ or $S / \beta^{\circ}$ thalassaemia with time

2 averaged mean Transcranial Doppler ultrasonography (TCD) velocities of $\geq 200$

$3 \mathrm{~cm} / \mathrm{sec}$ in the internal carotid or middle cerebral artery (Stroke Prevention Trial in

4 Sickle Cell Anemia study - STOP) (Adams, et al 1998). Regular red cell transfusion

5 reduced the risk of an initial stroke by 92\% (Adams, et al 1998), This was confirmed

6 in the Optimizing Primary Stroke Prevention in Sickle Cell Anemia (STOP2) Trial,

7 where children whose transfusions were discontinued were more likely to have a

8 stroke or to revert to abnormal TCD velocities than those who continued on regular

9 transfusion (Adams and Brambilla 2005)

11 The role of hydroxycarbamide in maintaining normal TCD velocities in children 12 without severe cerebral vasculopathy or prior transient ischaemic attack (TIA) who have received transfusions for at least one year (mean 4 years) for primary stroke prevention has recently been investigated in the TCD With Transfusions Changing to Hydroxyurea (TWiTCH) trial (Ware, et al 2015). In this randomised trial, hydroxycarbamide at maximum tolerated dose (alternative group) was compared to standard transfusions (standard group) after patients randomised to hydroxycarbamide had been slowly weaned off transfusions over 4-9 months. This trial showed that hydroxycarbamide is non-inferior to transfusions for the maintenance of TCD velocities and can be used as a substitute to help prevent primary stroke after discontinuation of initial transfusion therapy.

The role of transfusion in the management of children with sickle cell anaemia aged 5-15 years (median 10 years) with silent cerebral infarcts was investigated in the Silent Cerebral Infarct Multi-Center Clinical Trial (SIT) (DeBaun, et al 2014). In this randomised trial, children with $S S$ or $S / \beta^{\circ}$ thalassaemia with silent cerebral infarcts and normal or conditional TCD velocities were randomised to receive monthly transfusions to a target $\mathrm{Hb}$ of $90 \mathrm{~g} / \mathrm{l}$ and $\mathrm{HbS}<30 \%$ or standard care (observation group) for three years. The primary endpoint was recurrence of infarction, defined as a stroke, or new or enlarged silent cerebral infarct. The transfused group had a relative risk reduction of recurrence of infarction of $58 \%$ compared to the observation group; however, this was mainly due to a reduction in stroke incidence rather than a 
1 reduction in silent infarcts by transfusions. The authors recommended a screening

2 Magnetic Resonance Imaging (MRI) scan of the brain to identify children who may

3 benefit from medical or educational intervention. However, MRI is difficult to perform

4 without sedation in children $<7$ years old, the age group in which the majority of

5 silent cerebral infarcts occur.

\section{Recommendations}

Transfusion to maintain $\mathrm{HbS}<\mathbf{3 0} \%$ should be offered to children at high risk of stroke following Transcranial Doppler (TCD) screening. Transfusion is the recommended initial treatment to prevent stroke in such children (Grade 1A).

Hydroxycarbamide treatment should be considered for the primary prevention of stroke in children with high TCD velocities but not severe MRA-defined cerebral vasculopathy after an initial period of transfusion of at least 1 year (Grade 1A). The duration of the initial period of transfusion should be tailored to the individual patient; the transition to hydroxycarbamide should be done gradually and transfusion should be withdrawn after the hydroxycarbamide has been escalated to the maximum tolerated dose.

Treatment options including transfusion should be discussed with families of children who are found to have silent cerebral infarcts. Transfusion should be offered to children who are identified as being at greatest risk for recurrence of infarction after discussion of its benefits and risks (Grade 1A)

\subsubsection{Secondary stroke prevention in children with SCD}

The risk of recurrent stroke in children with SCD is very high. In a natural history study of 35 patients with a history of one or more strokes, the recurrence rate was $67 \%$ over a 9 year period, with $80 \%$ of the recurrent episodes occurring within 36 months of the initial event (Powars, et al 1978). 
2 There have been no randomised trials comparing the use of transfusion to no

3 intervention for prevention of recurrent stroke in SCD. Several single centre studies

4 (Balkaran, et al 1992, Lusher, et al 1976, Russell, et al 1984, Sarnaik, et al 1979)

5 and two multi-centre retrospective studies (Pegelow, et al 1995, Scothorn, et al 2002) all reported a clear benefit of transfusion in reducing the risk of recurrence in patients who had suffered one or more previous episodes of cerebral infarction.

9 In the Stroke With Transfusions Changing to Hydroxyurea (SWiTCH) trial, a non-

10 inferiority trial which compared transfusion to $\mathrm{HbS}<30 \%$ plus chelation with

11 hydroxycarbamide plus phlebotomy for the composite endpoint of secondary stroke

12 prevention and improved control of iron overload, there were no cases of recurrent

13 stroke in the transfused patients compared with $10 \%$ in the hydroxycarbamide/phlebotomy arm (Ware, et al 2012). The trial was closed early because even though the increased stroke risk in the hydroxycarbamide arm was within the predicted $12 \%$ rate, it was not offset by a reduction in iron overload through phlebotomy. Therefore, the authors concluded that transfusion and chelation remain a better way to manage children with sickle cell anaemia, stroke and iron overload.

Although the risk of stroke is not completely eliminated by regular transfusions (Hulbert, et al 2011, Pegelow, et al 1995, Scothorn, et al 2002), transfusions to maintain $\mathrm{HbS}<30 \%$ remains the recommended intervention to prevent stroke recurrence in children with SCD. There is some evidence from a small observational study that patients on transfusion programmes for secondary stroke prevention may be maintained on a less rigorous target of $\mathrm{HbS}<50 \%$ with little increased risk of stroke recurrence, provided they have been neurologically stable for at least 4 years after the initial stroke (Cohen, et al 1992).

\section{Recommendation}


1 Long-term transfusion to maintain $\mathrm{HbS}<\mathbf{3 0 \%}$ is recommended for the

2 prevention of recurrent ischaemic stroke due to sickle cell disease in children

3 (Grade 1B).

4

\section{$5 \quad$ 5.1.4 Primary stroke prevention in adults with SCD}

6 Adults with sickle cell anaemia are at increased risk of ischaemic and haemorrhagic

7 stroke; the risk of ischaemic stroke is highest after the age of 30 years, whereas

8 haemorrhagic stroke is most common in the 20-29 year age group (Ohene-

9 Frempong, et al 1998). TCD has not been validated in adults and there is currently

10 no tool for systematically assessing stroke risk. Studies to evaluate the efficacy of

11 transfusion for primary stroke prevention in defined adult SCD populations have not

12 been undertaken.

\subsubsection{Secondary stroke prevention in adults with SCD}

Whilst neurological events such as transient ischaemic attack or seizures may be the initial presentation of sickle cell cerebrovascular disease, adults experiencing such episodes should be fully investigated for other possible causes (e.g. atrial fibrillation, carotid artery stenosis). Data on transfusion for secondary stroke prevention in adult SCD is limited. An observational study (Powars, et al 1978) which included some adult subjects strongly suggests that the risk of further strokes is likely to be high without intervention. Current practice is to perform chronic transfusions in adults who have suffered a stroke attributable to SCD (NHLBI 2014,

23 Sickle Cell Society 2008).

\section{Recommendation}

Long-term transfusion to maintain $\mathrm{HbS}<30 \%$ is recommended for the (Grade 1B). 


\section{$1 \quad$ 5.1.6 Duration of transfusions for stroke prevention}

2 The optimal duration of transfusion is uncertain. Data from the STOP 2 trial indicated

3 that patients who were maintained on transfusion for a follow up period of 65 months

4 for primary stroke prevention had a $93 \%$ lower stroke risk than patients who discontinued transfusions after 30 months (Adams and Brambilla 2005). The results of the TWiTCH trial show that hydroxycarbamide is efficacious and non-inferior to blood transfusions for primary stroke prevention in children without severe cerebral vasculopathy or prior TIA who have been on transfusion for at least a year (mean 4 years) (Ware, et al 2015). However, the trial did not establish the optimal duration of transfusions prior to the switchover to hydroxycarbamide. Therefore, we suggest that the duration of this initial period of transfusions is assessed on a case by case basis.

For patients who have had a stroke, the risk of recurrent stroke is highest in the first three years after the initial event (Balkaran, et al 1992, Pegelow, et al 1995, Powars, et al 1978, Russell, et al 1984), suggesting that maintaining a $\mathrm{HbS}$ level $<30 \%$ is especially important during this period. The benefits of transfusions beyond this period are debatable. Recurrent stroke has been reported within 12 months of prospectively stopping transfusions in 5 out of 10 children who had been on a transfusion programme for as long as 9.5 years (Wang, et al 1991). Therefore, transfusion for secondary stroke prevention may need to continue indefinitely (NHLBI 2014, Sickle Cell Society 2008), but the decision to continue transfusions should be tailored to the needs of individual patients; it should be regularly reviewed and risk/benefit considerations must be discussed with the patient and/or parents. It has been suggested that where the stroke has occurred in the context of acute illness (e.g. aplastic crisis), transfusions may be discontinued after two years if repeat vascular imaging is normal at that time (RCP 2004)

\section{Recommendation}


1 concomitant severe cerebral vasculopathy or prior history of TIA,

2 hydroxycarbamide may be offered to such children after at least one year of

3 transfusions (Grade 1A) but the exact duration of transfusions should be tailored to the individual patient.

Long-term transfusion should be offered to children and adults who have suffered a previous ischaemic stroke due to sickle cell disease (Grade 1B).

\subsection{Recurrent acute chest syndrome}

ACS is a marker of SCD severity, being a risk factor for early death in SS patients $>20$ years (Castro, et al 1994, Platt, et al 1994) and $44 \%$ of patients will have recurrent episodes (Castro, et al 1994). Evidence suggests that chronic transfusion therapy is effective in reducing incidence and hospitalisation due to ACS (Hankins, et al 2005a, Miller, et al 2001, Styles and Vichinsky 1994). In the SIT trial, ACS was significantly reduced in comparison with untransfused patients with an incidence rate ratio of 0.13 (DeBaun, et al 2014). However, since there is a clear benefit of hydroxycarbamide for ACS prevention (Charache, et al 1995, Thornburg, et al 2012), transfusion should be considered only if hydroxycarbamide is ineffective or contraindicated.

Recommendation

Hydroxycarbamide is recommended as first line treatment for recurrent acute chest syndrome or repeated painful episodes. Regular transfusion should be considered for patients failing this treatment or for whom it is contraindicated (Grade 1B).

\subsection{Frequent painful crises}

28 The frequency of sickle cell painful crises is a marker of disease severity; SS

29 patients who are admitted to hospital $\geq 3$ times a year because of vaso-occlusive

30 crises are at increased risk of early death (Platt, et al 1991). Prolonged 
1 hospitalisations and high readmission rates are also associated with a higher

2 mortality (Ballas and Lusardi 2005, Houston-Yu, et al 2003).

3

4 Long-term transfusion may be of benefit in patients with recurrent painful crises. In a retrospective study, long-term blood transfusion significantly reduced the hospital admission frequency for vaso-occlusive crises from 2.20 to 0.21 per patient per year (Styles and Vichinsky 1994). In the STOP trial, the hospital admission rate for vasoocclusive crises in chronically transfused patients was significantly less than for patients on standard care ( $9.7 \vee 27.1$ events per 100 patient years) (Miller, et al 2001). In the SIT trial, incidence rates of painful crises were significantly reduced by transfusion with an incidence rate ratio of 0.41 (DeBaun, et al 2014).

However, hydroxycarbamide is very effective in reducing the rate of painful crises and ACS in both adults and children (Charache, et al 1995, Olivieri and Vichinsky 1998, Scott, et al 1996) and improves survival (Steinberg, et al 2003, Steinberg, et al 2010). Therefore, hydroxycarbamide is the first line therapy for patients with frequent vaso-occlusive crises with transfusion being reserved for those who do not respond or in whom hydroxycarbamide is contraindicated.

\section{Recommendation}

Transfusion, either by simple or exchange transfusion, should be considered in patients with frequent painful episodes requiring hospital dmssion (more detail?) where hydroxycarbamide is ineffective or contraindicated (Grade 1B)

\subsection{Other possible indications}

Transfusion has been used in a variety of sickle cell related problems, where clinical experience or case reports/series have suggested benefit. In patients with renal disease, transfusion may be considered in end stage renal disease, in those awaiting a renal transplant and post-renal transplant (Sharpe and Thein 2014). Transfusion has also been used in patients undergoing liver transplantation in the 
1 peri- transplant settings (Blinder, et al 2013, Gardner, et al 2014). Blood transfusion

2 in the treatment of pulmonary hypertension seems theoretically reasonable with the

3 aim of decreasing haemolysis and thereby nitric oxide scavenging and consequent pulmonary vasoconstriction and has been recommended for this purpose (Cho and Hambleton 2011, Machado and Gladwin 2005).

7 The incidence of priapism and symptomatic avascular necrosis was significantly decreased by transfusion in the randomised SIT trial with incidence rate ratios of 0.13 and 0.22 , respectively (DeBaun, et al 2014), but its benefit in the management of patients with established disease has not been proven in randomised trials.

12 Transfusion has been used for other conditions including leg ulcers (Delaney, et al

13 2013, Minniti, et al 2010) and progressive sickle retinopathy (Gustave, et al 2013, McKinney, et al 2015). In some cases the reported benefit from transfusion has seemed dramatic, but specific recommendations must await more extensive data.

\section{Recommendation}

Transfusion for indications where evidence is limited should be based on a case-by-case assessment after full risk-benefit analysis (Grade 2C).

\section{PREOPERATIVE TRANSFUSION}

Anaesthesia and surgery increase sickle-related complications, particularly acute chest syndrome, while transfusion reduces the risk of perioperative complications (Howard, et al 2013, Vichinsky, et al 1995). Meticulous attention should be paid to optimising all aspects of perioperative care including oxygenation, hydration and warmth, as well as anaesthetic and surgical technique. Close liaison between anaesthetist, surgeon and haematologist is essential to ensuring good outcomes. Complicated surgical procedures should be undertaken in centres where there is specialist haemoglobinopathy support. 
2 With regards to transfusion, the two key questions to consider are:

1. Should SCD patients be transfused routinely pre-operatively?

2. If transfused, what is the optimal regimen?

\section{$6 \quad 6.1$ Role of routine preoperative transfusion}

7 This has long been controversial with insufficient randomised trial data impacting on variability in practice across hospitals in England (Buck, et al 2005) and in other studies (Table 2). There have been advocates both of routine pre-operative transfusion (Bhattacharyya, et al 1993, Derkay, et al 1991, Fullerton, et al 1981, Janik and Seeler 1980) and selective transfusion (Bischoff, et al 1988, Fu, et al 2005, Griffin and Buchanan 1993, Homi, et al 1979, Leff, et al 2007, Oduro and Searle 1972). A large observational study showed that perioperative transfusion was associated with a significantly lower rate of SCD-related postoperative complications for SS patients undergoing low-risk procedures and for SC patients at all surgical risk levels (Koshy, et al 1995). However, these findings suggested that not all patients should routinely be transfused preoperatively. Another study showed that those receiving "no transfusion" suffered the highest overall SCD-related complication rate (32\%), chest syndrome rate (19\%) and mortality rate (5\%) but without significant difference between those randomised to aggressive or simple transfusion regimens (Haberkern, et al 1997)

The most compelling evidence to support preoperative transfusion comes from the Transfusion Alternatives Preoperatively in Sickle Cell Disease (TAPS) trial (Howard, et al 2013). This was a randomised controlled trial in which a total of $67 \mathrm{SS}$ and S $\beta^{\circ}$ thalassaemia patients undergoing low risk surgery (e.g. adenoidectomy, dental procedures) and medium risk surgery (e.g. joint replacement, cholecystectomy, tonsillectomy) were randomly assigned to either no transfusion or transfusion (simple transfusion if $\mathrm{Hb}<90 \mathrm{~g} / \mathrm{l}$, exchange transfusion if $\mathrm{Hb} \geq 90 \mathrm{~g} / \mathrm{l}$ to achieve estimated $\mathrm{HbS}<60 \%$ ) (Howard, et al 2013). Classification of surgical risk was in 
1 accordance with the Cooperative Study of Sickle Cell Disease criteria (Koshy 1995).

2 Significantly greater clinically important complications (39\% v $15 \%)$ and serious

3 adverse events (30\% $\vee 3 \%)$ were found in untransfused SS and $S / \beta^{\circ}$-thalassaemia compared to transfused patients undergoing low-risk and medium-risk surgery. The most common serious adverse event was ACS accounting for $91 \%$ of all serious events occurring in $27 \%$ of untransfused patients compared with $3 \%$ in transfused patients. Intraoperative or postoperative transfusion was increased in the patients who had not been transfused preoperatively (Howard, et al 2013).

Although the final number of subjects recruited into the trial at its termination was small, the TAPS study provided clear evidence to support preoperative transfusion in SS patients undergoing low-risk and medium-risk surgical procedures.

\subsection{Optimal preoperative transfusion regimen}

In a study by Vichinsky (Vichinsky, et al 1995) in SS and S/ $\beta^{\circ}$-thalassaemia patients, a top-up transfusion regimen to haemoglobin $100 \mathrm{~g} / \mathrm{l}$ was reported to be as effective as exchange transfusion to attain haemoglobin $100 \mathrm{~g} / \mathrm{l}$ and $\mathrm{HbS}<30 \%$ in preventing perioperative complications and was associated with a $50 \%$ lower risk of transfusion-related complications. However, it must be noted that the type of exchange transfusion procedure was not described and some of the exchange transfused patients required repeated simple transfusion. Furthermore, in $14 \%$ of patients in the exchange transfusion arm, post-transfusion \% $\mathrm{HbS}$ was substantially higher than the $30 \%$ target for a number of reasons including inadequate transfusion. Moreover, in the simple transfusion group, nearly $43 \%$ of the patients received "minimal transfusion therapy". Despite these limitations, the authors concluded that simple transfusion was as effective as exchange transfusion.

The issue of whether simple or aggressive transfusion had better outcomes was not addressed in the TAPS trial where the transfusion regimen was either simple transfusion if $\mathrm{Hb}<90 \mathrm{~g} / \mathrm{l}$ or partial exchange transfusion if $\mathrm{Hb} \geq 90 \mathrm{~g} / \mathrm{l}$, to a target $\mathrm{Hb}$ 
1 of $100 \mathrm{~g} / \mathrm{l}$ and estimated $\mathrm{HbS}<60 \%$ (Howard, et al 2013). Seventy-six percent of

2 transfused patients received simple transfusion, providing support for the efficacy of

3 a conservative transfusion regimen in reducing post-operative complications for the

4 relevant surgical procedures reported in the trial.

6 It is not possible to give dogmatic guidelines regarding the choice of type of

7 preoperative transfusion and transfusion targets; these should be tailored to the

8 individual patient, taking into account factors such as the type of surgery, the

9 severity of the patient's sickle cell disease and co-morbidities (see section 6.5).

10 However, it is reasonable to undertake simple transfusion for low and moderate risk

11 surgery if $\mathrm{Hb}$ is $<90 \mathrm{~g} / \mathrm{l}$ to achieve a post-transfusion $\mathrm{Hb}$ of $100 \mathrm{~g} / \mathrm{l}$. An exchange

12 transfusion should be considered for patients undergoing high risk surgery, patients

13 with severe sickle cell disease and those with significant co-morbidities.

\subsection{Emergency surgery}

16 Evidence for the role of transfusion in emergency surgery is very limited. In the 17 largest study on surgery in SCD, 717 patients underwent 1079 surgical procedures 18 of which 271 (25\%) were emergency procedures (Koshy, et al 1995). When all 19 procedures (elective + emergency) were considered, most patients undergoing 20 cholecystectomy and splenectomy were transfused preoperatively ( $94 \%$ of SS and $2182 \%$ of SC) as were those undergoing Caesarean section or hysterectomy ( $91 \%$ of SS and $72 \%$ of SC). As the data for postoperative outcomes were analysed together for elective and emergency procedures (rather than separately), it is not possible to assess the effect on transfusion on outcomes for SCD patients undergoing emergency surgery in this study.

Similarly, in another observational study, no separate analyses were carried for patients undergoing emergency surgery (Bischoff, et al 1988). In a further retrospective study where perioperative transfusion was used selectively and sparingly (Homi, et al 1979) 5 postoperative deaths occurred in 28 patients 
1 undergoing emergency surgery; however, it is not clear if these patients were

2 transfused preoperatively.

3

4 The important principle here is to not unnecessarily delay emergency surgery because of transfusion. A reasonable policy is to give a simple transfusion to patients who have $\mathrm{Hb}<90 \mathrm{~g} / \mathrm{l}$ and then proceed to surgery with minimal delay. If the $\mathrm{Hb}$ is $>90 \mathrm{~g} / \mathrm{l}$ and the surgical procedure is low risk, it is reasonable to proceed to surgery without delay while arrangements are made to transfuse the patient intraoperatively or post-operatively if necessary.

\subsection{Role of transfusion in surgery for sickle genotypes other than SS}

There is a paucity of evidence relating specifically to SC and other sickle genotypes.

3 One observational study suggested a benefit for transfusion in reducing the incidence of sickle cell-related postoperative complications for SC patients at all levels of surgical risk (Koshy, et al 1995), however, transfused SC patients undergoing low-risk surgery had higher rates of non-sickle cell postoperative complications (fever and bleeding) than untransfused patients. A further study demonstrated that preoperative transfusion was beneficial for moderate risk procedures, particularly abdominal surgery (Neumayr, et al 1998).

\subsection{Deciding which patients may benefit from preoperative transfusion.}

The TAPS trial has provided evidence for the efficacy of preoperative transfusion only for SS patients with preoperative $\mathrm{Hb}$ 60-90 g/l undergoing a narrow range of elective medium-risk surgical procedures (Howard, et al 2013). The trial's findings may not be applicable to many other surgical situations. However, on the basis of the findings, it is recommended that preoperative transfusion to an $\mathrm{Hb}$ of $100 \mathrm{~g} / \mathrm{l} \mathrm{be}$ considered a standard intervention in SS undergoing elective low-risk or medium-risk surgery as defined in the study (Howard, et al 2013). For other patients it is recommended that each case is judged on its own merits in consultation with the SHT. Transfusion should be considered when the risk of post-operative chest 
1 infection or ACS is high, but this has yet to be clearly shown in prospective trials.

2 Transfusion is also recommended for individuals with significant co-morbidities (e.g.

3 abnormal pulmonary, cardiac, renal and hepatic function) and in those undergoing high-risk surgical procedures or having lengthy surgical procedures (Wun 2009).

6 The optimal method of transfusion remains an open question but currently available evidence indicates that simple transfusion is not inferior to exchange transfusion in low- to medium-risk surgery (Howard, et al 2013, Vichinsky, et al 1995), However exchange transfusion is recommended for patients undergoing high-risk surgery,

10 although this has not been directly addressed in studies.

Recommendation

Preoperative transfusion (simple transfusion to $\mathrm{Hb} 100 \mathrm{~g} / \mathrm{l}$ if $\mathrm{Hb}<90 \mathrm{~g} / \mathrm{l}$ or partial exchange if $\mathrm{Hb} \geq 90 \mathrm{~g} / \mathrm{l}$ ) is recommended for SS patients undergoing low and medium-risk surgery (Grade $1 \mathrm{~A}$ ).

Exchange transfusion is recommended for all patients with SS requiring highrisk surgery (Grade 1C).

Preoperative transfusion is recommended for patients with SC undergoing moderate risk surgery and high risk surgery (Grade 1C).

All other patients undergoing surgery should be individually assessed taking into account previous history and complexity of surgery and a management plan should be formulated to include the need for transfusion (Grade 1C).

For patients requiring emergency surgery, the urgency and complexity of the procedure should be taken into account in the timing of perioperative transfusion. Provided transfusion will not result in undue delay to surgery, simple transfusion should be given preoperatively to a target $\mathrm{Hb}$ of $100 \mathrm{~g} / \mathrm{l}$ if the $\mathrm{Hb}$ is low. If $\mathrm{Hb} \geq 90 \mathrm{~g} / \mathrm{l}$ and surgical risk is low but transfusion will result in an unacceptable delay to surgery, it is reasonable to proceed to surgery 
1 without delay while arrangements are made to transfuse the patient intra-

2 operatively or post-operatively if necessary (Grade 1C).

\section{TRANSFUSION IN PREGNANCY}

Sickle cell disease in pregnancy is associated with an increased risk of both maternal and fetal complications (Serjeant, et al 2004, Smith, et al 1996, Villers, et al 2008). Maternal complications include sickle-related problems (notably painful crises, acute chest syndrome) and pregnancy-related syndromes such as pre-eclampsia, pre-term labour and an increased rate of Caesarean section (Villers, et al 2008).

\section{Fetal complications include intra-uterine growth restriction, prematurity and} increased rates of fetal loss (Serjeant, et al 2004). In a UK-wide observational study of 109 pregnancies in SCD, 52.3\% suffered painful crises during pregnancy and $12.8 \%$ within six weeks post-partum; $6.4 \%$ had ACS and $21.1 \%$ were admitted to intensive care in the peripartum period (Oteng-Ntim, et al 2014).

\section{There is a single prospective randomised controlled study which compared 36} pregnant SS women who were transfused prophylactically (simple or partial exchange transfusion commencing in first or second trimester; target $\mathrm{Hb}$ 100-110 g/l; target $\mathrm{HbS}<35 \%$ ) to a control group of 36 SS women who received transfusion only for medical or obstetric emergencies (Koshy, et al 1988). This study found a significant reduction in the incidence of painful crises and substantial decrease in other SCD-related complications in the group receiving prophylactic transfusions but no difference in medical and obstetric complications or fetal outcome between the two groups. Additionally, satisfactory pregnancy outcomes were observed in a nonrandomised group of SS, SC and $S / \beta$ thalassaemia women who were transfused only for medical or obstetric emergencies. In view of these results, the authors concluded that omitting prophylactic transfusions was not harmful to pregnant patients with SCD or their offspring and thus routine use of transfusions in pregnancy was not justified. However, this study had a number of significant limitations including small sample size and high risk of bias (Malinowski, et al2015). 
1 Other uncontrolled studies have shown conflicting evidence with some showing

2 evidence for a benefit of transfusion (Asma, et al 2015, Benites, et al 2015,

3 Cunningham, et al 1983, Gilli, et al 2007, Howard, et al 1995, Morrison, et al 1991)

4 whilst others did not (El-Shafei, et al 1995, Tuck, et al 1987). The study by Howard demonstrated a trend for reduced SCD-related complications in the third trimester in patients on prophylactic exchange transfusions, leading the authors to recommend prophylactic transfusions from the $26^{\text {th }}$ week of pregnancy onwards in SS patients (Howard, et al 1995). In a more recent retrospective study, high rates of painful sickle crises and other severe sickle complications occurred despite a policy of prophylactic partial exchange transfusions to maintain $\mathrm{HbS}<40 \%$ from $22-26$ weeks onwards for all sickle patients (Ngo, et al 2010), but there was no control arm not receiving prophylactic transfusion for comparison.

A Cochrane review which examined evidence from two small studies of low quality concluded that other than a marginal reduction in the rate of painful crises, prophylactic transfusion conferred no clear advantage over selective transfusion with regards to pregnancy outcome (Okusanya and Oladapo 2013). However, the findings of a more recent systematic review and meta-analysis which included 11 cohort studies and the RCT by Koshy et al (Koshy, et al 1988) suggested that prophylactic transfusion is associated with a reduction in vaso-occlusive episodes, maternal mortality, overall pulmonary complications, neonatal mortality and pre-term birth while acknowledging the methodological limitations of the original study designs 23 (Malinowski, et al 2015).

As a result of the limited and sometimes conflicting data, the use of prophylactic transfusion varies between centres. There is a consensus however that pregnant women with a history of severe SCD-related complications such as recurrent ACS, and stroke, individuals on chronic transfusion prior to pregnancy, and those with repeated sickle cell crises or exacerbation of anaemia during pregnancy should 30 receive transfusion (Koshy 1995, RCOG 2011, Sickle Cell Society 2008).

31 Prophylactic transfusion should also be considered for women with other serious 
1 medical or obstetric conditions or with a multiple pregnancy. (ACOG 2007, Koshy

2 1995, RCOG 2011).

3

4 It should be emphasised that pregnancy in women with SCD is high-risk and expert 5 obstetric care is essential to achieving good outcomes. The ideal standard of care is

6 joint management by obstetricians and haematologists who are experienced in the 7 care of SCD patients.

11 Recommendations

12 Transfusion is not routinely required for uncomplicated singleton pregnancies, 13 but should be considered for women at high risk of with sickle complications 14 during pregnancy (painful crises, acute chest syndrome, stroke etc.) (Grade 15 1B).

Prophylactic Transfusion should be considered in women with previous or current serious medical (such as chest synrome), obstetric or fetal problems, women with worsening anaemia, those on long-term transfusions for stroke prevention or for amelioration of severe sickle complications, women on hydroxycarbamide because of severe disease and those with a multiple pregnancy (Grade 1C).

Acknowledgement

We are indebted to Dr Alison Thomas for her help in the preparation of this guideline.

\section{Declarations of interest}

None of the authors has declared a conflict of interest.

\section{References}


ACOG (2007) ACOG Practice Bulletin No. 78: hemoglobinopathies in pregnancy. Obstet Gynecol, 109, 229-237.

Adams, R.J. \& Brambilla, D. (2005) Discontinuing prophylactic transfusions used to prevent stroke in sickle cell disease. $N$ Engl J Med, 353, 2769-2778.

Adams, R.J., McKie, V.C., Hsu, L., Files, B., Vichinsky, E., Pegelow, C., Abboud, M., Gallagher, D., Kutlar, A., Nichols, F.T., Bonds, D.R. \& Brambilla, D. (1998) Prevention of a first stroke by transfusions in children with sickle cell anemia and abnormal results on transcranial doppler ultrasonography. The New England Journal of Medicine, 339, 5-11.

Anderson, M.J., Kidd, I.M., Jones, S.E., Pattison, J.R., Grieco, M.H., Lange, M., Buimovici-Klein, E. \& Cooper, L.Z. (1985) Parvovirus infection and the acquired immunodeficiency syndrome. Ann Intern Med, 102, 275.

Aslam, A.F., Aslam, A.K. \& Dipillo, F. (2005) Fatal splenic sequestration crisis with multiorgan failure in an adult woman with sickle cell-beta+ thalassemia. Am J Med Sci, 329, 141-143.

Asma, S., Kozanoglu, I., Tarim, E., Sariturk, C., Gereklioglu, C., Akdeniz, A., Kasar, M., Turgut, N.H., Yeral, M., Kandemir, F., Boga, C. \& Ozdogu, H. (2015) Prophylactic red blood cell exchange may be beneficial in the management of sickle cell disease in pregnancy. Transfusion, 55, 36-44.

Balkaran, B., Char, G., Morris, J.S., Thomas, P.W., Serjeant, B.E. \& Serjeant, G.R. (1992) Stroke in a cohort of patients with homozygous sickle cell disease. $J$ Pediatr, 120, 360-366.

Ballas, S.K. \& Lusardi, M. (2005) Hospital readmission for adult acute sickle cell painful episodes: frequency, etiology, and prognostic significance. Am J Hematol, 79, 17-25.

Benites, B.D., Benevides, T.C., Valente, I.S., Marques, J.F., Jr., Gilli, S.C. \& Saad, S.T. (2015) The effects of exchange transfusion for prevention of complications during pregnancy of sickle hemoglobin C disease patients. Transfusion.

Bhattacharyya, N., Wayne, A.S., Kevy, S.V. \& Shamberger, R.C. (1993) Perioperative management for cholecystectomy in sickle cell disease. J Pediatr Surg, 28, 72-75.

Bischoff, R.J., Williamson, A., 3rd, Dalali, M.J., Rice, J.C. \& Kerstein, M.D. (1988) Assessment of the use of transfusion therapy perioperatively in patients with sickle cell hemoglobinopathies. Ann Surg, 207, 434-438.

Blinder, M.A., Geng, B., Lisker-Melman, M., Crippin, J.S., Korenblat, K., Chapman, W., Shenoy, S. \& Field, J.J. (2013) Successful orthotopic liver transplantation in an adult patient with sickle cell disease and review of the literature. Hematol Rep, 5, 1-4.

Brousse, V., Elie, C., Benkerrou, M., Odievre, M.H., Lesprit, E., Bernaudin, F., Grimaud, M., Guitton, C., Quinet, B., Dangiolo, S. \& de Montalembert, M. (2012) Acute splenic sequestration crisis in sickle cell disease: cohort study of 190 paediatric patients. Br J Haematol, 156, 643-648.

Brozovic, M., Davies, S.C. \& Brownell, A.I. (1987) Acute admissions of patients with sickle cell disease who live in Britain. Br Med J (Clin Res Ed), 294, 1206-1208.

Buck, J., Casbard, A., Llewelyn, C., Johnson, T., Davies, S. \& Williamson, L. (2005) Preoperative transfusion in sickle cell disease: a survey of practice in England. Eur J Haematol, 75, 14-21.

Castro, O., Brambilla, D.J., Thorington, B., Reindorf, C.A., Scott, R.B., Gillette, P., Vera, J.C. \& Levy, P.S. (1994) The acute chest syndrome in sickle cell disease: 
incidence and risk factors. The Cooperative Study of Sickle Cell Disease. Blood, 84, 643-649.

Charache, S., Terrin, M.L., Moore, R.D., Dover, G.J., Barton, F.B., Eckert, S.V., McMahon, R.P. \& Bonds, D.R. (1995) Effect of hydroxyurea on the frequency of painful crises in sickle cell anemia. Investigators of the Multicenter Study of Hydroxyurea in Sickle Cell Anemia. $N$ Engl J Med, 332, 1317-1322.

Cho, G. \& Hambleton, I.R. (2011) Regular long-term red blood cell transfusions for managing chronic chest complications in sickle cell disease. Cochrane Database Syst Rev, CD008360.

Cohen, A.R., Martin, M.B., Silber, J.H., Kim, H.C., Ohene-Frempong, K. \& Schwartz, E. (1992) A modified transfusion program for prevention of stroke in sickle cell disease. Blood, 79, 1657-1661.

Cunningham, F.G., Pritchard, J.A. \& Mason, R. (1983) Pregnancy and sickle cell hemoglobinopathies: results with and without prophylactic transfusions. Obstet Gynecol, 62, 419-424.

DeBaun, M.R., Gordon, M., McKinstry, R.C., Noetzel, M.J., White, D.A., Sarnaik, S.A., Meier, E.R., Howard, T.H., Majumdar, S., Inusa, B.P., Telfer, P.T., Kirby-Allen, M., McCavit, T.L., Kamdem, A., Airewele, G., Woods, G.M., Berman, B., Panepinto, J.A., Fuh, B.R., Kwiatkowski, J.L., King, A.A., Fixler, J.M., Rhodes, M.M., Thompson, A.A., Heiny, M.E., Redding-Lallinger, R.C., Kirkham, F.J., Dixon, N., Gonzalez, C.E., Kalinyak, K.A., Quinn, C.T., Strouse, J.J., Miller, J.P., Lehmann, H., Kraut, M.A., Ball, W.S., Jr., Hirtz, D. \& Casella, J.F. (2014) Controlled trial of transfusions for silent cerebral infarcts in sickle cell anemia. N Engl J Med, 371, 699-710.

Delaney, K.M., Axelrod, K.C., Buscetta, A., Hassell, K.L., Adams-Graves, P.E., Seamon, C., Kato, G.J. \& Minniti, C.P. (2013) Leg ulcers in sickle cell disease: current patterns and practices. Hemoglobin, 37, 325-332.

Derkay, C.S., Bray, G., Milmoe, G.J. \& Grundfast, K.M. (1991) Adenotonsillectomy in children with sickle cell disease. South Med J, 84, 205-208.

Dick, M. (2010) Sickle cell disease in childhood: standards and guidelines for clinical care 2nd Edition. London.

El-Shafei, A.M., Kaur Dhaliwal, J., Kaur Sandhu, A. \& Rashid Al-Sharqi, M. (1995) Indications for blood transfusion in pregnancy with sickle cell disease. Aust $N \mathrm{Z} \mathrm{J}$ Obstet Gynaecol, 35, 405-408.

Emond, A.M., Collis, R., Darvill, D., Higgs, D.R., Maude, G.H. \& Serjeant, G.R. (1985) Acute splenic sequestration in homozygous sickle cell disease: natural history and management. $J$ Pediatr, 107, 201-206.

Emre, U., Miller, S.T., Gutierez, M., Steiner, P., Rao, S.P. \& Rao, M. (1995) Effect of transfusion in acute chest syndrome of sickle cell disease. J Pediatr, 127, 901-904.

Fu, T., Corrigan, N.J., Quinn, C.T., Rogers, Z.R. \& Buchanan, G.R. (2005) Minor elective surgical procedures using general anesthesia in children with sickle cell anemia without pre-operative blood transfusion. Pediatr Blood Cancer, 45, 43-47.

Fullerton, M.W., Philippart, A.I., Sarnaik, S. \& Lusher, J.M. (1981) Preoperative exchange transfusion in sickle cell anemia. J Pediatr Surg, 16, 297-300.

Gardner, K., Suddle, A., Kane, P., O'Grady, J., Heaton, N., Bomford, A. \& Thein, S.L. (2014) How we treat sickle hepatopathy and liver transplantation in adults. Blood, 123, 2302-2307. 
Gilli, S.C., De Paula, E.V., Biscaro, F.P., Marques, J.F., Costa, F.F. \& Saad, S.T. (2007) Third-trimester erythrocytapheresis in pregnant patients with sickle cell disease. Int J Gynaecol Obstet, 96, 8-11.

Goldstein, A.R., Anderson, M.J. \& Serjeant, G.R. (1987) Parvovirus associated aplastic crisis in homozygous sickle cell disease. Arch Dis Child, 62, 585-588.

Griffin, T.C. \& Buchanan, G.R. (1993) Elective surgery in children with sickle cell disease without preoperative blood transfusion. J Pediatr Surg, 28, 681-685.

Gulbis, B., Haberman, D., Dufour, D., Christophe, C., Vermylen, C., Kagambega, F., Corazza, F., Devalck, C., Dresse, M.F., Hunninck, K., Klein, A., Le, P.Q., Loop, M., Maes, P., Philippet, P., Sariban, E., Van Geet, C. \& Ferster, A. (2005) Hydroxyurea for sickle cell disease in children and for prevention of cerebrovascular events: the Belgian experience. Blood, 105, 2685-2690.

Gustave, B.W., Oliver, S.C., Mathias, M., Velez-Montoya, R., Quiroz-Mercado, H., Olson, J.L., Mandava, N. \& Bhandari, R. (2013) Reversal of paracentral occlusive retinopathy in a case of sickle cell disease using exchange transfusion. Ophthalmic Surg Lasers Imaging Retina, 44, 505-507.

Gutteridge, C., Newland, A.C. \& Sequeira, J. (1985) Hepatic sequestration in sickle cell anemia. Br Med J (Clin Res Ed), 290, 1214-1215.

Haberkern, C.M., Neumayr, L.D., Orringer, E.P., Earles, A.N., Robertson, S.M., Black, D., Abboud, M.R., Koshy, M., Idowu, O. \& Vichinsky, E.P. (1997) Cholecystectomy in sickle cell anemia patients: perioperative outcome of 364 cases from the National Preoperative Transfusion Study. Preoperative Transfusion in Sickle Cell Disease Study Group. Blood, 89, 1533-1542.

Hankins, J., Jeng, M., Harris, S., Li, C.S., Liu, T. \& Wang, W. (2005a) Chronic transfusion therapy for children with sickle cell disease and recurrent acute chest syndrome. J Pediatr Hematol Oncol, 27, 158-161.

Hankins, J.S., Ware, R.E., Rogers, Z.R., Wynn, L.W., Lane, P.A., Scott, J.P. \& Wang, W.C. (2005b) Long-term hydroxyurea therapy for infants with sickle cell anemia: the HUSOFT extension study. Blood, 106, 2269-2275.

Hassell, K.L., Eckman, J.R. \& Lane, P.A. (1994) Acute multiorgan failure syndrome: a potentially catastrophic complication of severe sickle cell pain episodes. $\mathrm{Am} \mathrm{J}$ Med, 96, 155-162.

Hatton, C.S., Bunch, C. \& Weatherall, D.J. (1985) Hepatic sequestration in sickle cell anaemia. Br Med J (Clin Res Ed), 290, 744-745.

Homi, J., Reynolds, J., Skinner, A., Hanna, W. \& Serjeant, G. (1979) General anaesthesia in sickle-cell disease. $\mathrm{Br}$ Med J, 1, 1599-1601.

Houston-Yu, P., Rana, S.R., Beyer, B. \& Castro, O. (2003) Frequent and prolonged hospitalizations: a risk factor for early mortality in sickle cell disease patients. Am J Hematol, 72, 201-203.

Howard, J., Hart, N., Roberts-Harewood, M., Cummins, M., Awogbade, M., Davis, B. \& Committee, B. (2015) Guideline on the management of acute chest syndrome in sickle cell disease. Br J Haematol, 169, 492-505.

Howard, J., Malfroy, M., Llewelyn, C., Choo, L., Hodge, R., Johnson, T., Purohit, S., Rees, D.C., Tillyer, L., Walker, I., Fijnvandraat, K., Kirby-Allen, M., Spackman, E., Davies, S.C. \& Williamson, L.M. (2013) The Transfusion Alternatives Preoperatively in Sickle Cell Disease (TAPS) study: a randomised, controlled, multicentre clinical trial. Lancet, 381, 930-938. 
Howard, R.J., Tuck, S.M. \& Pearson, T.C. (1995) Pregnancy in sickle cell disease in the UK: Results of a multicentre survey of the effect of prophylactic blood transfusion on maternal and fetal outcome. British Journal of Obstetrics \& Gynaecology, 102, 947-951.

Hulbert, M.L., McKinstry, R.C., Lacey, J.L., Moran, C.J., Panepinto, J.A., Thompson, A.A., Sarnaik, S.A., Woods, G.M., Casella, J.F., Inusa, B., Howard, J., Kirkham, F.J., Anie, K.A., Mullin, J.E., Ichord, R., Noetzel, M., Yan, Y., Rodeghier, M. \& Debaun, M.R. (2011) Silent cerebral infarcts occur despite regular blood transfusion therapy after first strokes in children with sickle cell disease. Blood, 117, 772-779.

Hulbert, M.L., Scothorn, D.J., Panepinto, J.A., Scott, J.P., Buchanan, G.R., Sarnaik, S., Fallon, R., Chu, J.Y., Wang, W., Casella, J.F., Resar, L., Berman, B., Adamkiewicz, T., Hsu, L.L., Smith-Whitley, K., Mahoney, D., Woods, G., Watanabe, M. \& DeBaun, M.R. (2006) Exchange blood transfusion compared with simple transfusion for first overt stroke is associated with a lower risk of subsequent stroke: a retrospective cohort study of 137 children with sickle cell anemia. J Pediatr, 149, 710-712.

Janik, J. \& Seeler, R.A. (1980) Perioperative management of children with sickle hemoglobinopathy. J Pediatr Surg, 15, 117-120.

Josephson, C.D., Su, L.L., Hillyer, K.L. \& Hillyer, C.D. (2007) Transfusion in the patient with sickle cell disease: a critical review of the literature and transfusion guidelines. Transfus Med Rev, 21, 118-133.

King, K.E., Shirey, R.S., Lankiewicz, M.W., Young-Ramsaran, J. \& Ness, P.M. (1997) Delayed hemolytic transfusion reactions in sickle cell disease: simultaneous destruction of recipients' red cells. Transfusion, 37, 376-381.

Kinney, T.R., Helms, R.W., O'Branski, E.E., Ohene-Frempong, K., Wang, W., Daeschner, C., Vichinsky, E., Redding-Lallinger, R., Gee, B., Platt, O.S. \& Ware, R.E. (1999) Safety of hydroxyurea in children with sickle cell anemia: results of the HUG-KIDS study, a phase I/II trial. Pediatric Hydroxyurea Group. Blood, 94, $1550-1554$.

Kinney, T.R., Ware, R.E., Schultz, W.H. \& Filston, H.C. (1990) Long-term management of splenic sequestration in children with sickle cell disease. Journal of Pediatrics, 117, 194-199.

Koshy, M. (1995) Sickle cell disease and pregnancy. Blood Review, 9, 157-164.

Koshy, M., Burd, L., Wallace, D., Moawad, A. \& Baron, J. (1988) Prophylactic red-cell transfusions in pregnant patients with sickle cell disease. A randomized cooperative study. The New England Journal of Medicine, 319, 1447-1452.

Koshy, M., Weiner, S.J., Miller, S.T., Sleeper, L.A., Vichinsky, E., Brown, A.K., Khakoo, Y. \& Kinney, T.R. (1995) Surgery and anesthesia in sickle cell disease. Cooperative study of sickle cell diseases. Blood, 86, 3676-3684.

Lee, E.S. \& Chu, P.C. (1996) Reverse sequestration in a case of sickle crisis. Postgrad Med J, 72, 487-488.

Leff, D.R., Kaura, T., Agarwal, T., Davies, S.C., Howard, J. \& Chang, A.C. (2007) A nontransfusional perioperative management regimen for patients with sickle cell disease undergoing laparoscopic cholecystectomy. Surg Endosc, 21, 1117-1121.

Lowenthal, E.A., Wells, A., Emanuel, P.D., Player, R. \& Prchal, J.T. (1996) Sickle cell acute chest syndrome associated with parvovirus B19 infection: case series and review. Am J Hematol, 51, 207-213. 
Lusher, J.M., Haghighat, H. \& Khalifa, A.S. (1976) A prophylactic transfusion program for children with sickle cell anemia complicated by CNS infarction. Am J Hematol, 1, 265-273.

Machado, R.F. \& Gladwin, M.T. (2005) Chronic sickle cell lung disease: new insights into the diagnosis, pathogenesis and treatment of pulmonary hypertension. $\mathrm{Br} \mathrm{J}$ Haematol, 129, 449-464.

Malinowski, A.K., Shehata, N., D'Souza, R., Kuo, K.H., Ward, R., Shah, P.S. \& Murphy, K. (2015) Prophylactic transfusion for pregnant women with sickle cell disease: a systematic review and meta-analysis. Blood, 126, 2424-2435.

McCarthy, L.J., Vattuone, J., Weidner, J., Skipworth, E., Fernandez, C., Jackson, L., Rothenberger, S., Waxman, D., Miraglia, C., Porcu, P. \& Danielson, C.F. (2000) Do automated red cell exchanges relieve priapism in patients with sickle cell anemia? Ther Apher, 4, 256-258.

McKinney, C.M., Siringo, F., Olson, J.L., Capocelli, K.E., Ambruso, D.R. \& Nuss, R. (2015) Red cell exchange transfusion halts progressive proliferative sickle cell retinopathy in a teenaged patient with hemoglobin SC disease. Pediatr Blood Cancer.

Merritt, A.L., Haiman, C. \& Henderson, S.O. (2006) Myth: blood transfusion is effective for sickle cell anemia-associated priapism. CJEM, 8, 119-122.

Miller, S.T., Wright, E., Abboud, M., Berman, B., Files, B., Scher, C.D., Styles, L., Adams, R.J. \& Investigators, S. (2001) Impact of chronic transfusion on incidence of pain and acute chest syndrome during the Stroke Prevention Trial (STOP) in sickle-cell anemia. J Pediatr, 139, 785-789.

Milner, P.F., Squires, J.E., Larison, P.J., Charles, W.T. \& Krauss, J.S. (1985) Posttransfusion crises in sickle cell anemia: role of delayed hemolytic reactions to transfusion. South Med J, 78, 1462-1469.

Minniti, C.P., Eckman, J., Sebastiani, P., Steinberg, M.H. \& Ballas, S.K. (2010) Leg ulcers in sickle cell disease. Am J Hematol, 85, 831-833.

Montague, D.K., Jarow, J., Broderick, G.A., Dmochowski, R.R., Heaton, J.P., Lue, T.F., Nehra, A., Sharlip, I.D., Members of the Erectile Dysfunction Guideline Update, P. \& Americal Urological, A. (2003) American Urological Association guideline on the management of priapism. $J$ Urol, 170, 1318-1324.

Morrison, J.C., Morrison, F.S., Floyd, R.C., Roberts, W.E., Hess, L.W. \& Wiser, W.L. (1991) Use of continuous flow erythrocytapheresis in pregnant patients with sickle cell disease. J Clin Apher, 6, 224-229.

Neumayr, L., Koshy, M., Haberkern, C., Earles, A.N., Bellevue, R., Hassell, K., Miller, S., Black, D. \& Vichinsky, E. (1998) Surgery in patients with hemoglobin SC disease. Preoperative Transfusion in Sickle Cell Disease Study Group. Am J Hematol, 57, 101-108.

Ngo, C., Kayem, G., Habibi, A., Benachi, A., Goffinet, F., Galacteros, F. \& Haddad, B. (2010) Pregnancy in sickle cell disease: maternal and fetal outcomes in a population receiving prophylactic partial exchange transfusions. Eur J Obstet Gynecol Reprod Biol, 152, 138-142.

NHLBI (2014) Evidence-Based Management of Sickle Cell Disease: Expert Panel Report, 2014. National Heart, Lung, and Blood Institute, Bethesda, MD. Available at http://www.nhlbi.nih.gov/health-pro/guidelines/sickle-cell-diseaseguidelines. 
NICE (2008) Stroke: Diagnosis and initial management of acute stroke and transient ischaemic attack (TIA). NICE clinical guideline 68. National Institute for Health and Care Excellence, London. Available at https://www.nice.org.uk/guidance/cg68.

Oduro, K.A. \& Searle, J.F. (1972) Anaesthesia in sickle-cell states: a plea for simplicity. Br Med J, 4, 596-598.

Ohene-Frempong, K. (2001) Indications for red cell transfusion in sickle cell disease. Semin Hematol, 38, 5-13.

Ohene-Frempong, K., Weiner, S.J., Sleeper, L.A., Miller, S.T., Embury, S., Moohr, J.W., Wethers, D.L., Pegelow, C.H. \& Gill, F.M. (1998) Cerebrovascular accidents in sickle cell disease: rates and risk factors. Blood, 91, 288-294.

Okusanya, B.O. \& Oladapo, O.T. (2013) Prophylactic versus selective blood transfusion for sickle cell disease in pregnancy. Cochrane Database Syst Rev, 12, CD010378.

Olivieri, N.F. \& Vichinsky, E.P. (1998) Hydroxyurea in children with sickle cell disease: impact on splenic function and compliance with therapy. J Pediatr Hematol Oncol, 20, 26-31.

Oteng-Ntim, E., Ayensah, B., Knight, M. \& Howard, J. (2014) Pregnancy outcome in patients with sickle cell disease in the UK - a national cohort study comparing sickle cell anaemia (HbSS) with HbSC disease. Br J Haematol.

Pattison, J.R., Jones, S.E., Hodgson, J., Davis, L.R., White, J.M., Stroud, C.E. \& Murtaza, L. (1981) Parvovirus infections and hypoplastic crisis in sickle-cell anaemia. Lancet, 1, 664-665.

Pegelow, C.H., Adams, R.J., McKie, V., Abboud, M., Berman, B., Miller, S.T., Olivieri, N., Vichinsky, E., Wang, W. \& Brambilla, D. (1995) Risk of recurrent stroke in patients with sickle cell disease treated with erythrocyte transfusions. Journal of Pediatrics, 126, 896-899.

Petz, L.D., Calhoun, L., Shulman, I.A., Johnson, C. \& Herron, R.M. (1997) The sickle cell hemolytic transfusion reaction syndrome. Transfusion, 37, 382-392.

Platt, O.S., Brambilla, D.J., Rosse, W.F., Milner, P.F., Castro, O., Steinberg, M.H. \& Klug, P.P. (1994) Mortality in sickle cell disease. Life expectancy and risk factors for early death. $N$ Engl $J$ Med, 330, 1639-1644.

Platt, O.S., Thorington, B.D., Brambilla, D.J., Milner, P.F., Rosse, W.F., Vichinsky, E. \& Kinney, T.R. (1991) Pain in sickle cell disease. Rates and risk factors. $N$ Engl J Med, 325, 11-16.

Powars, D., Wilson, B., Imbus, C., Pegelow, C. \& Allen, J. (1978) The natural history of stroke in sickle cell disease. American Journal of Medicine, 65, 461-471.

Quirolo, K. (2010) How do I transfuse patients with sickle cell disease? Transfusion, 50, 1881-1886.

RCOG (2011) Management of Sickle Cell Disease in Pregnancy. Green-top Guideline No. 61. Royal College of Obstetricians and Gynaecologists, London. Available at https://www.rcog.org.uk/en/guidelines-research-services/guidelines/gtg61/.

RCP (2004) Stroke in childhood: clinical guidelines for diagnosis, management and rehabilitation. Paediatric Stroke Working Group, Royal College of Physicians, London. Available at https://www.rcplondon.ac.uk/publications/strokechildhood.

Roshkow, J.E. \& Sanders, L.M. (1990) Acute splenic sequestration crisis in two adults with sickle cell disease: US, CT, and MR imaging findings. Radiology, 177, 723725. 
Russell, M.O., Goldberg, H.I., Hodson, A., Kim, H.C., Halus, J., Reivich, M. \& Schwartz, E. (1984) Effect of transfusion therapy on arteriographic abnormalities and on recurrence of stroke in sickle cell disease. Blood, 63, 162169.

Sarnaik, S., Soorya, D., Kim, J., Ravindranath, Y. \& Lusher, J. (1979) Periodic transfusions for sickle cell anemia and CNS infarction. Am J Dis Child, 133, 1254-1257.

Scothorn, D.J., Price, C., Schwartz, D., Terrill, C., Buchanan, G.R., Shurney, W., Sarniak, I., Fallon, R., Chu, J.Y., Pegelow, C.H., Wang, W., Casella, J.F., Resar, L.S., Berman, B., Adamkiewicz, T., Hsu, L.L., Ohene-Frempong, K., SmithWhitley, K., Mahoney, D., Scott, J.P., Woods, G.M., Watanabe, M. \& Debaun, M.R. (2002) Risk of recurrent stroke in children with sickle cell disease receiving blood transfusion therapy for at least five years after initial stroke. $J$ Pediatr, 140, 348-354.

Scott, J.P., Hillery, C.A., Brown, E.R., Misiewicz, V. \& Labotka, R.J. (1996) Hydroxyurea therapy in children severely affected with sickle cell disease. $J$ Pediatr, 128, 820-828.

Serjeant, B.E., Hambleton, I.R., Kerr, S., Kilty, C.G. \& Serjeant, G.R. (2001) Haematological response to parvovirus B19 infection in homozygous sickle-cell disease. Lancet, 358, 1779-1780.

Serjeant, G.R., Loy, L.L., Crowther, M., Hambleton, I.R. \& Thame, M. (2004) Outcome of pregnancy in homozygous sickle cell disease. Obstet Gynecol, 103, 1278-1285.

Serjeant, G.R., Serjeant, B.E., Thomas, P.W., Anderson, M.J., Patou, G. \& Pattison, J.R. (1993) Human parvovirus infection in homozygous sickle cell disease. Lancet, 341, 1237-1240.

Serjeant, G.R., Serjeant, B.E. (2001) Sickle cell disease. Oxford University Press, New York.

Serjeant, G.R., Topley, J.M., Mason, K., Serjeant, B.E., Pattison, J.R., Jones, S.E. \& Mohamed, R. (1981) Outbreak of aplastic crises in sickle cell anaemia associated with parvovirus-like agent. Lancet, 2, 595-597.

Shao, S.H. \& Orringer, E.P. (1995) Sickle cell intrahepatic cholestasis: approach to a difficult problem. Am J Gastroenterol, 90, 2048-2050.

Sharpe, C.C. \& Thein, S.L. (2014) How I treat renal complications in sickle cell disease. Blood, 123, 3720-3726.

Sickle, Cell Society. (2008) Standards for the Clinical Care of Adults with Sickle Cell Disease in the UK.

Smith-Whitley, K., Zhao, H., Hodinka, R.L., Kwiatkowski, J., Cecil, R., Cecil, T., Cnaan, A. \& Ohene-Frempong, K. (2004) Epidemiology of human parvovirus B19 in children with sickle cell disease. Blood, 103, 422-427.

Smith, J.A., Espeland, M., Bellevue, R., Bonds, D., Brown, A.K. \& Koshy, M. (1996) Pregnancy in sickle cell disease: experience of the Cooperative Study of Sickle Cell Disease. Obstet Gynecol, 87, 199-204.

Steinberg, M.H., Barton, F., Castro, O., Pegelow, C.H., Ballas, S.K., Kutlar, A., Orringer, E., Bellevue, R., Olivieri, N., Eckman, J., Varma, M., Ramirez, G., Adler, B., Smith, W., Carlos, T., Ataga, K., DeCastro, L., Bigelow, C., Saunthararajah, Y., Telfer, M., Vichinsky, E., Claster, S., Shurin, S., Bridges, K., Waclawiw, M., Bonds, D. \& Terrin, M. (2003) Effect of hydroxyurea on 
mortality and morbidity in adult sickle cell anemia: risks and benefits up to 9 years of treatment. JAMA, 289, 1645-1651.

Steinberg, M.H., McCarthy, W.F., Castro, O., Ballas, S.K., Armstrong, F.D., Smith, W., Ataga, K., Swerdlow, P., Kutlar, A., DeCastro, L., Waclawiw, M.A., Investigators of the Multicenter Study of Hydroxyurea in Sickle Cell, A. \& Follow-Up, M.S.H.P. (2010) The risks and benefits of long-term use of hydroxyurea in sickle cell anemia: A 17.5 year follow-up. Am J Hematol, 85, 403408.

Styles, L.A. \& Vichinsky, E. (1994) Effects of a long-term transfusion regimen on sickle cell-related illnesses. J Pediatr, 125, 909-911.

Thornburg, C.D., Files, B.A., Luo, Z., Miller, S.T., Kalpatthi, R., Iyer, R., Seaman, P., Lebensburger, J., Alvarez, O., Thompson, B., Ware, R.E., Wang, W.C. \& Investigators, B.H. (2012) Impact of hydroxyurea on clinical events in the BABY HUG trial. Blood, 120, 4304-4310; quiz 4448.

Topley, J.M., Rogers, D.W., Stevens, M.C. \& Serjeant, G.R. (1981) Acute splenic sequestration and hypersplenism in the first five years in homozygous sickle cell disease. Arch Dis Child, 56, 765-769.

Tuck, S.M., James, C.E., Brewster, E.M., Pearson, T.C. \& Studd, J.W. (1987) Prophylactic blood transfusion in maternal sickle cell syndromes. Br J Obstet Gynaecol, 94, 121-125.

Turner, J.M., Kaplan, J.B., Cohen, H.W. \& Billett, H.H. (2009) Exchange versus simple transfusion for acute chest syndrome in sickle cell anemia adults. Transfusion, 49, 863-868.

Vichinsky, E.P., Haberkern, C.M., Neumayr, L., Earles, A.N., Black, D., Koshy, M., Pegelow, C., Abboud, M., Ohene-Frempong, K. \& Iyer, R.V. (1995) A comparison of conservative and aggressive transfusion regimens in the perioperative management of sickle cell disease. The Preoperative Transfusion in Sickle Cell Disease Study Group. $N$ Engl J Med, 333, 206-213.

Vichinsky, E.P., Neumayr, L.D., Earles, A.N., Williams, R., Lennette, E.T., Dean, D., Nickerson, B., Orringer, E., McKie, V., Bellevue, R., Daeschner, C. \& Manci, E.A. (2000) Causes and outcomes of the acute chest syndrome in sickle cell disease. National Acute Chest Syndrome Study Group. $N$ Engl J Med, 342, 18551865.

Vichinsky, E.P., Styles, L.A., Colangelo, L.H., Wright, E.C., Castro, O. \& Nickerson, B. (1997) Acute chest syndrome in sickle cell disease: clinical presentation and course. Cooperative Study of Sickle Cell Disease. Blood, 89, 1787-1792.

Villers, M.S., Jamison, M.G., De Castro, L.M. \& James, A.H. (2008) Morbidity associated with sickle cell disease in pregnancy. Am J Obstet Gynecol, 199, 125 e121-125.

Wang, W.C., Kovnar, E.H., Tonkin, I.L., Mulhern, R.K., Langston, J.W., Day, S.W., Schell, M.J. \& Wilimas, J.A. (1991) High risk of recurrent stroke after discontinuance of five to twelve years of transfusion therapy in patients with sickle cell disease. J Pediatr, 118, 377-382.

Wang, W.C., Wynn, L.W., Rogers, Z.R., Scott, J.P., Lane, P.A. \& Ware, R.E. (2001) A two-year pilot trial of hydroxyurea in very young children with sickle-cell anemia. J Pediatr, 139, 790-796.

Wanko, S.O. \& Telen, M.J. (2005) Transfusion management in sickle cell disease. Hematol Oncol Clin North Am, 19, 803-826, v-vi. 
Ware, R.E., Davis, B.R., Schultz, W.H., Brown, R.C., Aygun, B., Sarnaik, S., Odame, I., Fuh, B., George, A., Owen, W., Luchtman-Jones, L., Rogers, Z.R., Hilliard, L., Gauger, C., Piccone, C., Lee, M.T., Kwiatkowski, J.L., Jackson, S., Miller, S.T., Roberts, C., Heeney, M.M., Kalfa, T.A., Nelson, S., Imran, H., Nottage, K., Alvarez, O., Rhodes, M., Thompson, A.A., Rothman, J.A., Helton, K.J., Roberts, D., Coleman, J., Bonner, M.J., Kutlar, A., Patel, N., Wood, J., Piller, L., Wei, P., Luden, J., Mortier, N.A., Stuber, S.E., Luban, N.L., Cohen, A.R., Pressel, S. \& Adams, R.J. (2015) Hydroxycarbamide versus chronic transfusion for maintenance of transcranial doppler flow velocities in children with sickle cell anaemia-TCD With Transfusions Changing to Hydroxyurea (TWiTCH): a multicentre, open-label, phase 3, non-inferiority trial. Lancet.

Ware, R.E., Helms, R.W. \& Investigators, S.W. (2012) Stroke With Transfusions Changing to Hydroxyurea (SWiTCH). Blood, 119, 3925-3932.

Wierenga, K.J., Serjeant, B.E. \& Serjeant, G.R. (2001) Cerebrovascular complications and parvovirus infection in homozygous sickle cell disease. $J$ Pediatr, 139, 438442.

Wright, J.G., Hambleton, I.R., Thomas, P.W., Duncan, N.D., Venugopal, S. \& Serjeant, G.R. (1999) Postsplenectomy course in homozygous sickle cell disease. J Pediatr, 134, 304-309.

Wun, T., Hassell, K. (2009) Best practices for transfusion for patients with sickle cell disease. Hematology Reviews, 1, e22. 